\title{
Determination of amino acid requirements of young pigs using an indicator amino acid
}

\author{
BY KYU-IL KIM1, IAN MCMILLAN ${ }^{2}$ AND HENRY S. BAYLEY* \\ Departments of Nutrition ${ }^{1}$ and Animal and Poultry Science ${ }^{2}$, University of Guelph, \\ Guelph, Ontario NIG 2W1, Canada
}

(Received 13 January 1983-Accepted 13 April 1983)

1. Mixtures of skim milk and free amino acids were compared as diets for pigs which would allow manipulation of dietary amino acid levels. Piglets gained $208 \mathrm{~g} / \mathrm{d}$ between 3 and $14 \mathrm{~d}$ of age on the skim-milk diet, but replacement of $600 \mathrm{~g} / \mathrm{kg}$ of the dietary nitrogen with free amino acids reduced growth rate to $148 \mathrm{~g} / \mathrm{d}$.

2. Supplementation of a lysine-deficient diet with lysine reduced the catabolism of $\left[{ }^{14} \mathrm{C}\right]$ phenylalanine showing that phenylalanine catabolism could be used as an indicator of the adequacy of diet with respect to another essential amino acid.

3. The dietary level of phenylalanine which would provide an excess for catabolism by the piglet was estimated directly by measuring the influence of dietary phenylalanine level on $\left[{ }^{14} \mathrm{C}\right]$ phenylalanine oxidation. Reduction of the dietary phenylalanine level below $7 \mathrm{~g} / \mathrm{kg}$ had no effect on phenylalanine oxidation, whereas increasing the dietary phenylalanine level above $7 \mathrm{~g} / \mathrm{kg}$ resulted in a linear increase in phenylalanine oxidation.

4. An indirect estimate of histidine requirement was made by examining the influence of dietary histidine level on $\left[{ }^{14} \mathrm{C}\right]$ phenylalanine oxidation. In diets containing more than $4 \mathrm{~g}$ histidine $/ \mathrm{kg}$, phenylalanine oxidation was minimal. In diets containing less than $4 \mathrm{~g}$ histidine $/ \mathrm{kg},\left[{ }^{14} \mathrm{C}\right]$ phenylalanine oxidation increased as the level of dietary histidine was reduced. This showed that the utilization of the essential amino acid phenylalanine, for protein synthesis, was not limited by histidine supply in diets containing more than $4 \mathrm{~g}$ histidine $/ \mathrm{kg}$.

5. A direct estimate of histidine requirement was made by examining the influence of dietary histidine level on $\left[{ }^{14} \mathrm{C}\right]$ histidine oxidation. Diets with more than $4 \mathrm{~g}$ histidine/ $\mathrm{kg}$ contained an excess which was catabolized: there was a linear increase in histidine oxidation in response to dietary histidine levels greater than $4 \mathrm{~g} / \mathrm{kg}$. This confirmed the previous indirect estimate of histidine requirement.

Amino acids absorbed from the digestive tract which are not used for protein synthesis and other essential functions enter the general pool of tissue fuels to be either oxidized or stored as fuels primarily through fatty acid synthesis. The objective in defining amino acid requirements is to allow the formulation of diets which will maximize the use of the essential amino acids for protein synthesis. Amino acid requirements are usually determined from observation of growth rates of animals receiving graded levels of a particular amino acid. Because growth is affected by more complex factors than the adequacy of the dietary amino acid balance, many observations of physiological responses to changes in amino acid levels in the diets have been used to define amino acid requirement. Brookes et al. (1972) used the amino acid oxidation technique to show the dietary lysine level which provided an excess for catabolism hence indicating the lysine requirement.

This procedure has been used by Chavez \& Bayley (1976) to measure the lysine requirement of young pigs; administration of the lysine dose as a single intravenous infusion to pigs which were receiving diets with graded levels of lysine necessitated the application of a correction for the differing extents of initial dilution of the tracer in the plasma. Kang-Lee \& Harper (1977) administered tracer doses of $\left[\mathrm{U}-{ }^{14} \mathrm{C}\right]$ histidine to rats in diets containing graded levels of histidine and measured the release of radioactivity in the expired carbon dioxide; they measured the specific activity of the liver free histidine at the end of their collection period to account for differences in dilution of the tracer. Such measurements 
of the effect of varying the level of an amino acid in the diet on its catabolism require a source of suitably-labelled tracer for each of the essential amino acids.

This constraint led to the present studies of the effect of feeding graded levels of one amino acid on the oxidation of another. The effect of dietary histidine level on phenylalanine oxidation has been measured so that phenylalanine catabolism could be used as an indicator of the adequacy of the dietary histidine supply. This indirect estimate of histidine requirement could then be confirmed by measurement of the effect of dietary histidine level on histidine oxidation, because of the availability of $\left[{ }^{14} \mathrm{C}\right]$ histidine. To enable such studies to be carried out, it was first necessary to develop a diet which would allow manipulation of the amino acid levels without impairing growth.

\section{EXPERIMENTAL}

\section{Animals}

Piglets from the University herd of Yorkshire-type pigs were weaned at $3 \mathrm{~d}$ of age and transferred to a windowless laboratory which was illuminated continuously and maintained at $30^{\circ}$. The mean weight of the piglets used in these studies was $1.7 \mathrm{~kg}$ at $3 \mathrm{~d}$ of age. They were housed in individual wire cages and were provided with supplementary heat from heat lamps. The diets were homogenized with water $(1: 4, w / w)$ and cooled before feeding. Food was offered every $3 \mathrm{~h}$ between 08.00 and 23.00 hours.

\section{Radioactively-labelled amino acids}

$\mathrm{L}-\left[1-{ }^{14} \mathrm{C}\right] \mathrm{phenylalanine}(60.4 \mathrm{mCi} / \mathrm{mmol})$ and $\mathrm{L}-\left[1{ }^{14} \mathrm{C}\right]$ histidine $(55.9 \mathrm{mCi} / \mathrm{mmol})$ were purchased from New England Nuclear Corporation, Boston, Massachusetts, in $1.0 \mathrm{M}$ - and $0.1 \mathrm{M}$-hydrochloric acid respectively. Both amino acids were subjected to ion-exchange chromatography and at least $98 \%$ of the radioactivity was recovered with the amino acid.

\section{In vivo recovery of ${ }^{14} \mathrm{CO}_{2}$}

Piglets were placed in Perspex chambers $(400 \times 400 \times 600 \mathrm{~mm}$ ) from which air could be withdrawn and passed over a cold condenser to remove water vapour and then passed through two gas-washing bottles containing a mixture of ethanolamine-ethylene glycol monomethyl ether $(1: 2, \mathrm{v} / \mathrm{v})$ to remove $\mathrm{CO}_{2}$. Radioactivity of the $\mathrm{CO}_{2}$ was determined by adding a $1 \mathrm{ml}$ portion of the absorbing mixture to $2 \mathrm{ml} \mathrm{NCS} \mathrm{(Amersham,} \mathrm{Oakville,} \mathrm{Ontario)}$ and $15 \mathrm{ml}$ Tritosol (Fricke, 1975) using a liquid-scintillation spectrometer (model Delta 300; Searle Analytical, Des Plaines, Illinois). The count rates were corrected for background and for counting efficiency using the channels-ratio method.

The procedure was verified by measuring the recovery of $\mathrm{CO}_{2}$ released from $\mathrm{Na}_{2}{ }^{14} \mathrm{CO}_{3}$. When the $\mathrm{CO}_{2}$ was released by acidifying the $\mathrm{Na}_{2} \mathrm{CO}_{3}$ with 1 M-hydrochloric acid, more than $98 \%$ of the activity was recovered. When $2 \mu \mathrm{Ci} \mathrm{Na}_{2}{ }^{14} \mathrm{CO}_{3}$ in saline $(9 \mathrm{~g}$ sodium chloride/1) was infused into the jugular veins of piglets, $92 \%$ of the activity was recovered in a $4 \mathrm{~h}$ period following the infusion. To obtain these recoveries it was necessary to maintain the pressure inside the chamber below atmospheric pressure, and the experiments were carried out with a pressure difference equal to $140 \mathrm{~mm}$ water. The air flow-rate through the apparatus was $12 \mathrm{l} / \mathrm{min}$.

\section{Determination of specific activities of liver free phenylalanine and histidine}

Piglets were killed by an intracardiac injection of sodium pentobarbital, and two samples of liver, each of approximately $15 \mathrm{~g}$, were removed and surface blood blotted into absorbent paper. One sample was frozen as a reserve and the other was chilled on ice before being homogenized with $10 \mathrm{ml}$ water (Omni-mixer; Ivan Sorval Inc., Norwalk, Connecticut). Protein was precipitated with $10 \mathrm{ml}$ trichloroacetic acid $(300 \mathrm{~g} / \mathrm{l})$ and the $15000 \mathrm{~g}$ super- 
natant fraction was applied to a cation-exchange resin (Dowex $50 \mathrm{WX} 8$, hydrogen form) in a column $12 \times 50 \mathrm{~mm}$. The column was washed with $10 \mathrm{ml}$ water and the amino acids eluted with $10 \mathrm{ml} 2 \mathrm{M}$-ammonium hydroxide. The eluate was evaporated to dryness at $50^{\circ}$ under reduced pressure in a rotary evaporator.

The dried sample was dissolved in $0.2 \mathrm{ml}$ lithium citrate buffer, $\mathrm{pH} 4.05$ for phenylalanine and $\mathrm{pH} \mathrm{7.0}$ for histidine, and applied to a column $(7 \times 300 \mathrm{~mm})$ packed with ion-exchange resin (type C-2 chromobeads; Technicon, Tarrytown, New York). The amino acids were eluted with the appropriate lithium citrate buffer with the column at $23^{\circ}$ for phenylalanine and $45^{\circ}$ for histidine. The flow-rate of the buffer was approximately $0.3 \mathrm{ml} / \mathrm{min}$ and the eluate was collected in fractions of $1.6 \mathrm{ml}$. Phenylalanine was usually recovered in the 25 th fraction and histidine in the 12th fraction. The radioactivity of the fraction was used to indicate the presence of the amino acid. Phenylalanine and histidine were the only amino acids in these fractions based on confirmatory analyses using either an amino acid analyzer (TSM amino acid AutoAnalyzer; Technicon) or gas-liquid chromatography (Adams, 1974). The column was regenerated by washing with $3 \mathrm{ml} 2 \mathrm{M}$-lithium hydroxide, followed by the appropriate lithium citrate buffer until the $\mathrm{pH}$ of the washings was either 4.05 or 7.0.

The specific activity of the amino acid in the fraction was calculated by measuring the concentration determined using ninhydrin, and the radioactivity determined by liquidscintillation counting. Duplicate $0.2 \mathrm{ml}$ samples of the appropriate fraction, along with samples of the next four fractions as blanks, were mixed with $1 \mathrm{ml}$ of a mixture of hydrazine sulphate and ninhydrin solutions $(3: 7, \mathrm{v} / \mathrm{v})$. These, along with suitable standards (20-200 nmol) were heated in a boiling water-bath for $10 \mathrm{~min}$, cooled in ice, and their absorbances at $570 \mathrm{~nm}$ measured. The fraction with the lowest absorbance was used as a blank in calculating the amino acid concentration. A further $0.4 \mathrm{ml}$ sample of the fraction containing the amino acid was mixed with $2 \mathrm{ml} \mathrm{NCS}$ and $15 \mathrm{ml}$ Tritosol for the determination of radioactivity as described for the $\mathrm{CO}_{2}$ absorbing mixtures.

The determinations required the following reagents:

Lithium citrate buffer, $p H 4 \cdot 05$. This contained (g): citric acid 10.5, lithium hydroxide $12 \cdot 6$, NaEDTA 1, phenol 0.1 ml, 'Brij-35' 3.0 (Atlas Chemical Industries, Brantford, Ontario) made to 11 with water, the $\mathrm{pH}$ adjusted with $6 \mathrm{M}-\mathrm{HCl}$ and filtered.

Lithium citrate buffer, $p H$ 7.0. This was made in the same way as the $\mathrm{pH} 4.05$ buffer except that $21 \mathrm{~g}$ lithium hydroxide were used.

Hydrazine sulphate ( $2 m \mathrm{~m}$ ). Hydrazine sulphate $1.049 \mathrm{~g}$, 'Brij-35' $6 \mathrm{~g}$, made to 11 with water.

Ninhydrin solution. This contained: ninhydrin $10 \mathrm{~g}$, ethylene glycol monomethyl ether $500 \mathrm{ml}$, sodium acetate buffer $250 \mathrm{ml}$, made to 11 with water.

Sodium acetate buffer. This contained: anhydrous sodium acetate $328 \mathrm{~g}$, glacial acetic acid $100 \mathrm{ml}$, made to 11 with water.

\section{Development of experimental dietary regimen}

Piglets can grow well on diets based on cows'-milk products, but the amino acid levels supplied by these diets are too high to allow their use as a basis for studying amino acid requirements. In preliminary experiments, diets containing isolated soya-bean protein or a hydrolysate of soya-bean protein which provided lower levels of specific amino acids were evaluated, but the piglets did not consume these diets readily and grew slowly, even when the diets were supplemented with amino acids. The piglets refused to consume a diet in which all the nitrogen was provided as free amino acids, but free amino acid diets were consumed if some skim-milk powder was included in the formulation.

Three diets were prepared in which all or a part of the $\mathrm{N}$ was provided as skim milk. Table 1 describes two of these; the third diet in which $200 \mathrm{~g} / \mathrm{kg}$ total $\mathrm{N}$ was provided by 
Table 1. Composition $(\mathrm{g} / \mathrm{kg})$ of experimental diets*

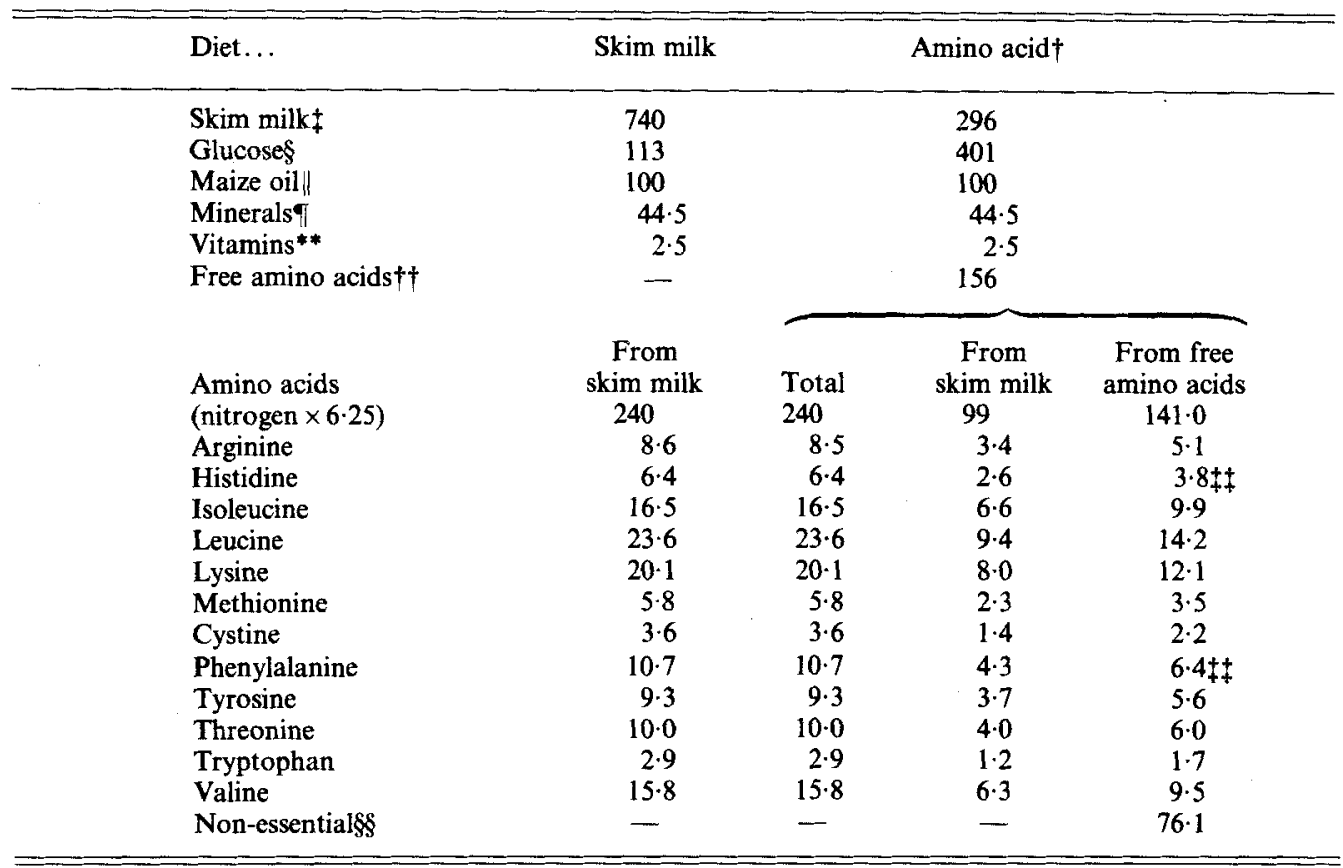

* Mixed with water $(1: 4, w / w)$, blended and cooled before feeding.

† Approximately $600 \mathrm{~g} / \mathrm{kg}$ total nitrogen was supplied as free amino acids.

$\$$ Crude protein $(\mathrm{N} \times 6.25) 330 \mathrm{~g} / \mathrm{kg}$ (Bonar and Bemis Ltd, Burlington, Ontario).

$\S$ Cerelose $^{\text {it }}$; Corn Products, CPC Int. Inc., Englewood Cliffs, New Jersey.

II Mazola ${ }^{8}$; Canada Starch Co. Ltd, Toronto, Ontario.

T As mg/kg dry diet: $\mathrm{CaH}_{4}\left(\mathrm{PO}_{4}\right)_{2} \cdot \mathrm{H}_{2} \mathrm{O} 24000, \mathrm{CaCO}_{3} 10500, \mathrm{NaCl} 3000, \mathrm{~K}_{2} \mathrm{CO}_{3} 1770, \mathrm{MgSO}_{4} \cdot 7 \mathrm{H}_{2} \mathrm{O} 4060$, $\mathrm{FeSO}_{4} \cdot 7 \mathrm{H}_{2} \mathrm{O} 625, \mathrm{ZnSO}_{4} .7 \mathrm{H}_{2} \mathrm{O} 435, \mathrm{MnSO}_{4} \cdot \mathrm{H}_{2} \mathrm{O} 61 \cdot 5, \mathrm{CuSO}_{4} \cdot 5 \mathrm{H}_{2} \mathrm{O} 23 \cdot 6, \mathrm{NaSeO}_{3} 0 \cdot 22$.

** As $\mathrm{mg} / \mathrm{kg}$ dry diet: niacin 44 , calcium D-panthothenate $28 \cdot 4$, riboflavin 6 , pyridoxine $3 \cdot 6$, thiamine hydrochloride 3.0, folic acid 2.0, D-biotin $0.2, \alpha$-tocopheryl acetate 15 , menadione 2 , retinyl acetate $0 \cdot 8$, cholecalciferol 0.011, cyanocobalamin 0.044, choline chloride 2000.

†† Total free amino acids. All amino acids were purchased from United States Biochemical Corp., Cleveland, Ohio. Lysine was supplied as lysine hydrochloride.

茫 Adjusted to appropriate levels for oxidation experiments.

$\$$ As $\mathrm{g} / \mathrm{kg}$ dry diet: alanine $8 \cdot 3$, aspartic acid $5 \cdot 3$, asparagine $5 \cdot 3$, glutamic acid $16 \cdot 3$, glutamine $16 \cdot 3$, glycine $16 \cdot 4$, proline $4 \cdot 1$, serine $4 \cdot 1$.

skim milk contained $(\mathrm{g} / \mathrm{kg})$ : 148 skim-milk powder, 212 amino acids, 493 glucose. The essential amino acids, except for the amino acid being studied, were added to the diets to equal the levels contained in the skim-milk diet. The non-essential amino- $\mathrm{N}$ was provided on the basis of observations of Rogers \& Harper (1965) who used free amino acid diets for rats, and of Robbins \& Baker (1978) who used free amino acid diets for weanling pigs. The acceptability of the diets to the piglets was improved by substituting cystine for cysteine because the latter had an unpleasant taste.

Four piglets were allocated to each diet when they were weaned at $3 \mathrm{~d}$ of age and their weight gains were monitored. The diet with the lowest level of skim milk was not consumed well by the piglets and this group was discarded when they were 10-d-old. The average daily growth rates of the piglets between 3 and $14 \mathrm{~d}$ of age were 208 and $148 \mathrm{~g}$ for the diets in which skim milk provided either all or $400 \mathrm{~g} / \mathrm{kg}$ dietary $\mathrm{N}$ respectively. The standard errors 
of these means were 18 and $13 \mathrm{~g}$. It was concluded that even though provision of $600 \mathrm{~g} / \mathrm{kg}$ dietary $\mathrm{N}$ as free amino acids reduced growth rate, this diet was a compromise which would support growth rates of $150 \mathrm{~g} / \mathrm{d}$ from 3 to $14 \mathrm{~d}$ of age.

\section{Influence of dietary lysine level on release of ${ }^{14} \mathrm{CO}_{2}$ from $\left[1-{ }^{14} \mathrm{C}\right]$ phenylalanine}

The hypothesis that catabolism of an essential amino acid would decrease if the supply of another essential amino acid in the diet was augmented from deficient to excess, was evaluated by measuring the release of ${ }^{14} \mathrm{CO}_{2}$ from $\left[{ }^{14} \mathrm{C}\right]$ phenylalanine in diets containing different levels of lysine. Initially, diets containing either 8 or $20 \mathrm{~g}$ lysine $/ \mathrm{kg}$ with $10.7 \mathrm{~g}$ phenylalanine $/ \mathrm{kg}$ were used, but the determination was repeated using diets containing a lower level of phenylalanine $(7.5 \mathrm{~g} / \mathrm{kg})$ to reduce the excess of phenylalanine being catabolized when the animal received an adequate amount of lysine. The piglets received the skim-milk-based diet for $3 \mathrm{~d}$ after weaning and then the amino acid diet for at least $7 \mathrm{~d}$ before the determination of phenylalanine catabolism.

\section{Calculation of the rate of amino acid catabolism}

Elwyn (1970) concluded that the liver is the major site of catabolism of phenylalanine and histidine. The measurements of radioactivity released as $\mathrm{CO}_{2}$ can be used to calculate actual rates of amino acid degradation from observations of their specific activities in the liver as follows:

$$
\text { Phenylalanine catabolism }(\mu \mathrm{mol} / \mathrm{kg} \text { per } \mathrm{h})=\frac{{ }^{14} \mathrm{CO}_{2}(\text { disintegrations } / \mathrm{min} \text { per } \mathrm{kg} \mathrm{per} \mathrm{h})}{\begin{array}{c}
\text { Specific activity of liver free phenylalanine } \\
\text { (disintegrations } / \text { min per } \mu \mathrm{mol})
\end{array}}
$$

The use of this relationship to calculate the phenylalanine catabolism rate assumes a steady-state of the liver free phenylalanine specific activity. The procedure used to administer the tracer dose of $\left[{ }^{14} \mathrm{C}\right]$ phenylalanine was designed to facilitate this; the pigs were fasted overnight and then received a meal of $150 \mathrm{ml}$ of the diet containing $10 \mu \mathrm{Ci}$ labelled phenylalanine. After $2 \mathrm{~h}$ they received a second meal of $150 \mathrm{ml}$ of the diet containing a further $10 \mu \mathrm{Ci}$ labelled phenylalanine. After a further $2 \mathrm{~h}$, the piglets were placed in the chambers which were then sealed and the air pumps started. The $\mathrm{CO}_{2}$ absorbers were by-passed for the first $15 \mathrm{~min}$ to allow the ${ }^{14} \mathrm{CO}_{2}$ to equilibrate in the ventilating air stream. $\mathrm{CO}_{2}$ was collected for $60 \mathrm{~min}$ and, at the end of this period, the pigs were killed and their livers removed.

\section{Influence of experimental regimen on the specific activity of liver free phenylalanine} To examine the stability of the specific activity of the liver free phenylalanine as a result of this feeding regimen, fifteen piglets were weaned at $3 \mathrm{~d}$ and received the skim-milk diet until $6 \mathrm{~d}$ of age and then the amino-acid diet until $14 \mathrm{~d}$ of age. The diet contained $8 \mathrm{~g}$ phenylalanine $/ \mathrm{kg}$. They all received the first meal containing $10 \mu \mathrm{Ci}$ phenylalanine; five were killed $2 \mathrm{~h}$ later and the other ten received the second meal, containing a further $10 \mu \mathrm{Ci}$ labelled phenylalanine. Five of these were killed $2 \mathrm{~h}$ after the second meal corresponding to the time at which the piglets were transferred to the apparatus to begin the $\mathrm{CO}_{2}$ collection. The remaining five were killed $3.25 \mathrm{~h}$ after the second meal, corresponding to the end of the $\mathrm{CO}_{2}$ collection period when the pigs would have been killed and their livers removed in the amino acid oxidation study. The specific activities $\left(\times 10^{3}\right.$ disintegrations/min per $\mu \mathrm{mol}$ ) of the liver free phenylalanine for the three groups were (mean with sE): $4.4(0.4)$, $5.3(0.9), 4.9(0.5)$. These values show that the feeding regimen had resulted in the establishment of a steady-state during the $1 \mathrm{~h} \mathrm{CO}_{2}$-collection period used in the amino acid 
oxidation study. These specific activities should be compared to the specific activity of the dietary phenylalanine which was $15.0 \times 10^{3}$ disintegrations $/ \mathrm{min}$ per $\mu \mathrm{mol}$.

\section{Influence of dietary phenylalanine level on phenylalanine oxidation}

To ensure maximum sensitivity of phenylalanine oxidation with respect to the adequacy of the dietary levels of the other essential amino acids, it is necessary, first, to avoid making the diet deficient in phenylalanine and, second, to avoid providing an excess of phenylalanine. A deficiency in phenylalanine would result in the underestimation of the requirement for the amino acid being studied. An excess would elevate phenylalanine oxidation when the levels of the other essential amino acids were adequate, thus decreasing the sensitivity of the procedure.

The dietary requirement for phenylalanine was estimated by measuring phenylalanine oxidation in piglets receiving diets containing graded levels of phenylalanine. The diets were based on the diet described in Table 1 in which skim milk provided $400 \mathrm{~g} / \mathrm{kg}$ of the dietary $\mathrm{N}$. The levels of the other essential amino acids were made equal to those in the control skim-milk diet by supplementing with crystalline amino acids. The skim milk contributed $4 \cdot 3 \mathrm{~g}$ phenylalanine $/ \mathrm{kg}$ diet and a series of diets containing $4 \cdot 3,5 \cdot 0,6 \cdot 0,7 \cdot 0,7 \cdot 5,8 \cdot 0,9 \cdot 0$ and $10.7 \mathrm{~g}$ phenylalanine $/ \mathrm{kg}$ were made by adding increasing supplements of L-phenylalanine. In this and subsequent experiments, the level of maize oil was increased to $200 \mathrm{~g} / \mathrm{kg}$ and the level of glucose reduced to $301 \mathrm{~g} / \mathrm{kg}$, to increase the energy level and to reduce the osmolarity of the diets.

A total of twenty-nine piglets were weaned at $3 \mathrm{~d}$ of age and received the skim-milk diet until $6 \mathrm{~d}$ of age when they all received the amino acid diet containing $10.7 \mathrm{~g}$ phenylalanine $/ \mathrm{kg}$ until they were at least 12 -d-old. On the day before the determination of the oxidation rate, the piglets were fasted overnight and the next day received two consecutive meals, the second $2 \mathrm{~h}$ after the first. The meals were $150 \mathrm{ml}$ of the appropriate diet and each meal contained $10 \mu \mathrm{Ci}\left[{ }^{14} \mathrm{C}\right]$ phenylalanine. At $2 \mathrm{~h}$ after the second meal, the piglets were transferred into the $\mathrm{CO}_{2}$-collection apparatus and $15 \mathrm{~min}$ later the $\mathrm{CO}_{2}$ was collected for $1 \mathrm{~h}$. At the end of this period, the pigs were killed and liver samples taken for determination of the specific activity of the liver free phenylalanine.

\section{Influence of dietary histidine level on phenylalanine oxidation}

Histidine was selected as an example of an essential amino acid whose dietary requirement could be estimated by the amino acid oxidation procedure both indirectly, using phenylalanine as an indicator, and directly, by studying the oxidation of histidine itself. This was possible because $\mathrm{L}-\left[1-{ }^{14} \mathrm{C}\right]$ histidine was available commercially.

This study was conducted with the diet used in the previous experiment. The skim milk contributed $2 \cdot 6 \mathrm{~g}$ histidine/ $\mathrm{kg}$ diet and a series of diets containing $2 \cdot 6,3 \cdot 0,3 \cdot 5,4 \cdot 0,5 \cdot 0$ and $6.0 \mathrm{~g}$ histidine $/ \mathrm{kg}$ were prepared by increasing supplements of $\mathrm{L}$-histidine. The phenylalanine level in these diets was $8.0 \mathrm{~g} / \mathrm{kg}$. A total of twenty-eight piglets were used in the experiment which was carried out as described for the previous experiment.

\section{Influence of dietary histidine level on histidine oxidation}

This estimation of the dietary histidine requirement was carried out using twenty piglets and a series of diets containing $2 \cdot 6,3.5,4 \cdot 0,4.5,5.0$ and $6.0 \mathrm{~g}$ histidine $/ \mathrm{kg}$. To allow determination of histidine oxidation rates, $10 \mu \mathrm{Ci}\left[{ }^{14} \mathrm{C}\right]$ histidine was included in each of the two meals offered to the piglets before collection of $\mathrm{CO}_{2}$, and the specific activity of the liver free histidine was determined at the end of the $\mathrm{CO}_{2}$-collection period. Otherwise the experiment was carried out in the same way as the indirect determination of histidine requirement. 
Table 2. Influence of dietary lysine level on release of ${ }^{14} \mathrm{CO}_{2}$ from $\left[{ }^{14} \mathrm{C}\right]$ phenylalanine

\begin{tabular}{|c|c|c|c|c|}
\hline \multirow{2}{*}{$\begin{array}{l}\text { Dietary } \\
\text { lysine } \\
(\mathrm{g} / \mathrm{kg})\end{array}$} & \multirow{2}{*}{$\begin{array}{c}\text { Dietary } \\
\text { phenylalanine } \\
(\mathrm{g} / \mathrm{kg})\end{array}$} & \multirow[b]{2}{*}{ No. of pigs* } & \multicolumn{2}{|c|}{$\begin{array}{l}\text { Activity recovered as } \\
\mathrm{CO}_{2} \text { (disintegrations/ } \\
\left.\min \left(\times 10^{-3}\right) \text { per } \mathrm{kg}\right)\end{array}$} \\
\hline & & & Mean & SE \\
\hline 8 & 10.7 & 6 & 454 & 38 \\
\hline 20 & 10.7 & 6 & 264 & 49 \\
\hline 8 & 7.5 & 4 & 251 & 29 \\
\hline 12 & $7 \cdot 5$ & 4 & 81 & 15 \\
\hline 16 & 7.5 & 4 & 93 & 22 \\
\hline 20 & $7 \cdot 5$ & 2 & 53 & 13 \\
\hline
\end{tabular}

* The mean (with SE) growth rate of the piglets was $117(7) \mathrm{g} / \mathrm{d}$.

\section{Statistical procedure}

Plots of amino acid oxidation $v$. dietary amino acid level indicated that the points could be segregated into two lines, one with almost zero slope and the other with a marked slope. The two lines were fitted to the values using the model described by Seber (1977):

$$
Y i=\alpha_{1}+\beta_{1} X i+\left(\alpha_{2}-\alpha_{1}\right) d+\left(\beta_{2}-\beta_{1}\right) d X i+e i,
$$

where $Y i$ is the amino acid oxidation rate, $\alpha_{1}$ and $\alpha_{2}$ are the intercepts of the first and second lines respectively, $\beta_{1}$ and $\beta_{2}$ are the gradients of the first and second lines respectively, $d$ is a coefficient having a value of 0 for the first line and 1 for the second line, and $e i$ is the residual error.

The standard errors were proportional to the means, and so the observations were weighted by an estimate of the sample variance (Draper \& Smith, 1981) which was estimated by regressing the observed sample variances over the corresponding sample means.

The allocation of the dietary amino acid levels between the first and second line was selected to give a minimum value for the residual error. Thus the regression procedure allowed and objective assessment of the change-over point, and the $95 \%$ confidence limits of the dietary amino acid level corresponding to the change-over point could be calculated (Seber, 1977).

\section{RESULTS}

Interaction of dietary lysine and phenylalanine levels on phenylalanine oxidation More radioactivity was released from the tracer dose of phenylalanine by the pigs which had received the diet deficient in lysine than by those which received the lysine-supplemented diet (Table 2). This confirmed the hypothesis that a reduction in the utilization of one essential amino acid for protein formation because of a dietary deficiency of another essential amino acid, could be detected by an increase in the release of labelled $\mathrm{CO}_{2}$ from the tracer dose of the indicator amino acid. The first observations were made using a diet supplying the same level of phenylalanine as the skim-milk diet; increasing the lysine level from deficient to sufficient resulted in a less than twofold reduction in the radioactivity released as $\mathrm{CO}_{2}$. When the determination was repeated using a diet with a lower level of phenylalanine to provide a smaller excess for catabolism, the increase in lysine level from deficient to sufficient resulted in a fourfold reduction in the radioactivity recovered as $\mathrm{CO}_{2}$. In this experiment there were no differences in the amounts of radioactivity recovered as $\mathrm{CO}_{2}$ among the three supplemental levels of lysine. This showed that the catabolism of the indicator amino acid was not influenced by increasing the dietary level of lysine above a 


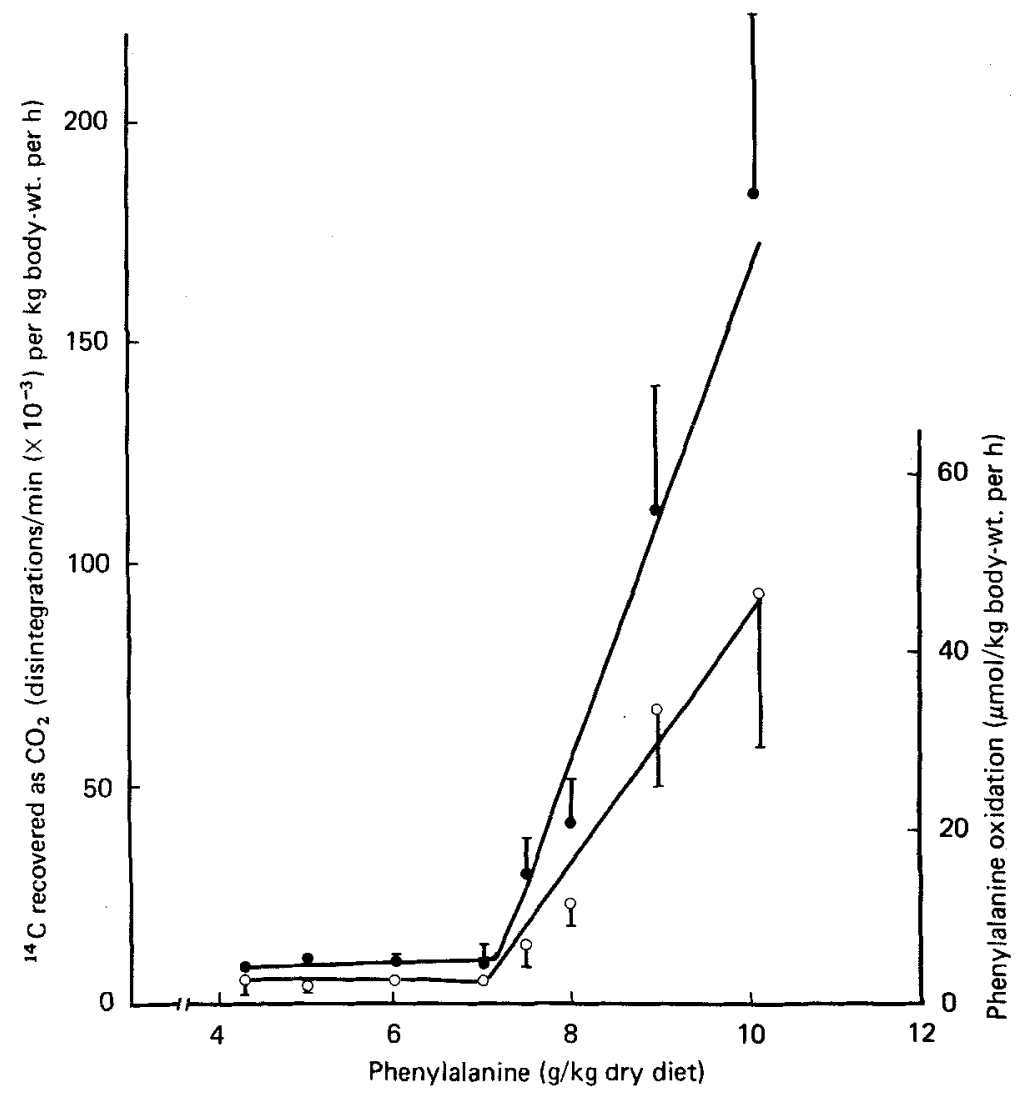

Fig. 1. Influence of dietary phenylalanine level on phenylalanine oxidation. Mean values with their standard errors represented by vertical bars for the radioactivity recovered as carbon dioxide ( $-\infty)$ and for phenylalanine oxidized $(\mathrm{O}-\mathrm{O})$ in $1 \mathrm{~h}$ by pigs which had received $20 \mu \mathrm{Ci}\left[\mathrm{L}-1{ }^{14} \mathrm{C}\right]$ phenylalanine in diets containing graded levels of phenylalanine. 'Broken-lines' were fitted by regression analysis; for the $\mathrm{CO}_{2}$ recovery the values for dietary phenylalanine levels of $4 \cdot 3-7 \cdot 0 \mathrm{~g} / \mathrm{kg}$ diet were ascribed to the first part of the regression line, and for the phenylalanine oxidized the values for dietary phenylalanine levels of $4 \cdot 3-6.0 \mathrm{~g} / \mathrm{kg}$ diet were ascribed to the first part of the regression line. Growth rate of the pigs from $3 \mathrm{~d}$ to day of determination (mean with $\mathrm{SE}$ ): $155(6) \mathrm{g} / \mathrm{d}$.

particular point. The results of this investigation emphasized the importance of selecting an appropriate dietary level of the indicator amino acid.

\section{Influence of dietary phenylalanine level on phenylalanine oxidation}

Increasing the level of phenylalanine in the diet from 4.3 to $7.0 \mathrm{~g} / \mathrm{kg}$ diet had no influence on the recovery of radioactivity in the $\mathrm{CO}_{2}$ (Fig. 1). However further increments up to $10.7 \mathrm{~g} / \mathrm{kg}$ resulted in a linear increase in the activity recovered in the $\mathrm{CO}_{2}$, indicating an increasing surplus available for oxidation. Provision of a constant amount of $\left[{ }^{14} \mathrm{C}\right]$ phenylalanine in diets containing increasing amounts of total phenylalanine resulted in a reduction in the specific activity of the dietary phenylalanine from 28 to $11 \times 10^{3}$ disintegrations/min per $\mu \mathrm{mol}$ (Table 3 ). In contrast, the specific activities of the liver free phenylalanine varied from 1.5 to $6.9 \times 10^{3}$ disintegrations $/ \mathrm{min}$ per $\mu \mathrm{mol}$ and were unrelated to the amount of phenylalanine in the diet. Comparison of the values for the diet and liver indicates the extent of dilution of the dietary phenylalanine with endogenous phenylalanine 
Table 3. Influence of dietary phenylalanine or histidine concentration $(\mathrm{g} / \mathrm{kg})$ on the specific activity of liver free phenylalanine or histidine (disintegrations $/ \mathrm{min}\left(\times 10^{-3}\right)$ per $\mu \mathrm{mol}$ )

\begin{tabular}{|c|c|c|c|c|}
\hline \multirow{2}{*}{$\begin{array}{l}\text { No. of } \\
\text { pigs }\end{array}$} & \multicolumn{2}{|c|}{ Dietary amino acid } & \multicolumn{2}{|c|}{$\begin{array}{l}\text { Liver free amino } \\
\text { acid specific } \\
\text { activity }\end{array}$} \\
\hline & Concentration & $\begin{array}{l}\text { Specific } \\
\text { activity }\end{array}$ & Mean & Range \\
\hline \multicolumn{5}{|c|}{$\begin{array}{l}\text { (a) Influence of dietary phenylalanine on phenylalanine oxidation } \\
\text { Phenylalanine Phenylalanine }\end{array}$} \\
\hline 2 & $4 \cdot 3$ & 28 & $2 \cdot 4$ & $1 \cdot 5-3 \cdot 3$ \\
\hline 2 & 5.0 & 24 & $5 \cdot 3$ & $3.8-6.9$ \\
\hline 4 & 6.0 & 20 & 3.4 & $2.4-4.8$ \\
\hline 4 & $7 \cdot 0$ & 17 & $4 \cdot 0$ & $2.4-5.6$ \\
\hline 5 & $7 \cdot 5$ & 16 & $3 \cdot 1$ & $2 \cdot 6-3 \cdot 7$ \\
\hline 5 & 8.0 & 15 & 3.9 & $2 \cdot 5-6 \cdot 7$ \\
\hline 4 & $9 \cdot 0$ & 13 & 3.4 & $2 \cdot 8-4 \cdot 6$ \\
\hline 3 & $10 \cdot 7$ & 11 & $4 \cdot 3$ & $3 \cdot 5-5 \cdot 5$ \\
\hline \multirow{2}{*}{\multicolumn{5}{|c|}{ (b) Influence of dietary histidine on phenylalanine oxidation }} \\
\hline & & & & \\
\hline 7 & $2 \cdot 6$ & 15 & $2 \cdot 5$ & $1.6-2.9$ \\
\hline 5 & $3 \cdot 0$ & 15 & $2 \cdot 6$ & $1 \cdot 2-3 \cdot 3$ \\
\hline 5 & 3.5 & 15 & $3 \cdot 2$ & $1 \cdot 9-4 \cdot 8$ \\
\hline 5 & 4.0 & 15 & 1.9 & $1.5-2.5$ \\
\hline 3 & $5 \cdot 0$ & 15 & 2.9 & $2 \cdot 8-3 \cdot 0$ \\
\hline 3 & $6 \cdot 0$ & 15 & $2 \cdot 2$ & $2 \cdot 0-2 \cdot 5$ \\
\hline \multirow{2}{*}{\multicolumn{5}{|c|}{$\begin{array}{c}\text { (c) Influence of dietary histidine on histidine oxidation } \\
\text { Histidine } \quad \text { Histidine }\end{array}$}} \\
\hline & & & & \\
\hline 2 & 2.6 & 44 & $3 \cdot 7$ & $3.7-3.7$ \\
\hline 4 & 3.5 & 33 & $6 \cdot 2$ & $3 \cdot 9-8 \cdot 8$ \\
\hline 3 & 4.0 & 29 & $3 \cdot 0$ & $2 \cdot 2-3 \cdot 9$ \\
\hline 4 & 4.5 & 25 & $4 \cdot 1$ & $2 \cdot 5-4 \cdot 8$ \\
\hline 4 & $5 \cdot 0$ & 23 & $8 \cdot 7$ & $4 \cdot 4-13.9$ \\
\hline 3 & $6 \cdot 0$ & 19 & $4 \cdot 7$ & $3 \cdot 0-5 \cdot 2$ \\
\hline
\end{tabular}

in the liver free amino acid pool, and emphasizes the importance of protein degradation as a source of amino acids for synthesis of new proteins.

Combination of the measurement of radioactivity recovered as $\mathrm{CO}_{2}$ with the specific activity of the liver free phenylalanine, allowed calculation of the oxidation rate of phenylalanine and these results are also shown in Fig. 1. Piglets receiving diets providing $7 \mathrm{~g}$ phenylalanine $/ \mathrm{kg}$ or less oxidized $3 \mu \mathrm{mol}$ phenylalanine $/ \mathrm{kg}$ body-weight per $\mathrm{h}$. Increasing the dietary phenylalanine level above $7 \mathrm{~g} / \mathrm{kg}$ increased phenylalanine oxidation, and the mean oxidation rate for the piglets receiving the diet containing $10.7 \mathrm{~g}$ phenylalanine $/ \mathrm{kg}$ was $46.4 \mu \mathrm{mol} / \mathrm{kg}$ body-weight per $\mathrm{h}$. The plots of radioactivity recovered as $\mathrm{CO}_{2}$, and of phenylalanine oxidation rates as functions of dietary phenylalanine level, both indicated that the amount of phenylalanine catabolized began to increase at the same dietary concentration because the specific activity of liver free phenylalanine was unrelated to dietary treatment. Regression analyses of the values in Fig. 1 showed that the change-over point for the release of activity in $\mathrm{CO}_{2}$ occurred with a dietary phenylalanine level of $7 \cdot 14 \mathrm{~g} / \mathrm{kg}(95 \%$ confidence limits $6.32-7.96 \mathrm{~g} / \mathrm{kg})$ and the change-over point for the oxidation of phenylalanine was at a dietary level of $7.03 \mathrm{~g} / \mathrm{kg}(95 \%$ confidence limits $6.68-7.38 \mathrm{~g} / \mathrm{kg}$ ), the greater precision of the latter estimate being due to the variability removed by the measurement of the specific activity of the liver free phenylalanine. These results show that the provision of more than $7 \mathrm{~g}$ phenylalanine $/ \mathrm{kg}$ diet resulted in an excess, 


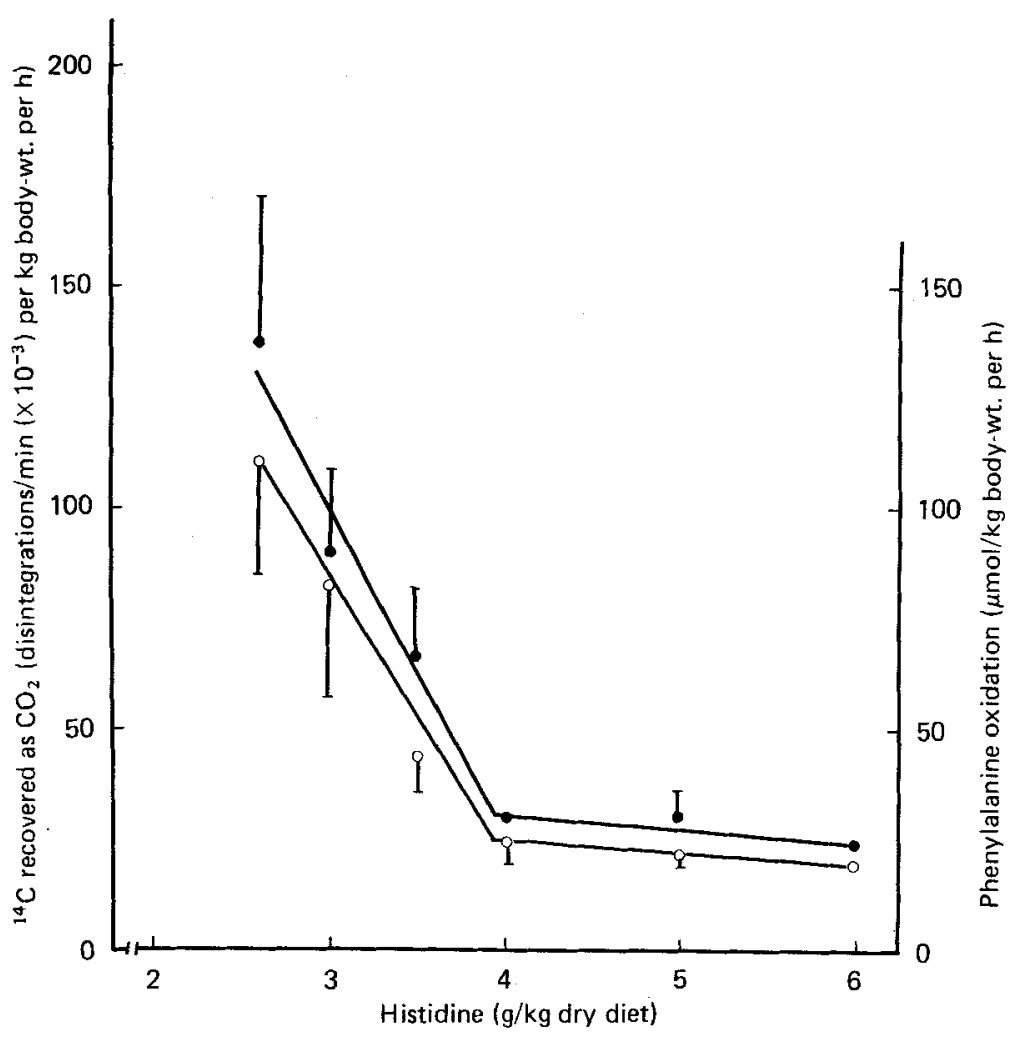

Fig. 2. Influence of dietary histidine level on phenylalanine oxidation. Mean values with their standard errors represented by vertical bars for the radioactivity recovered as carbon dioxide (--O) and for phenylalanine oxidized $(\mathrm{O}--\mathrm{O})$ in $1 \mathrm{~h}$ by pigs which had received $20 \mu \mathrm{Ci} \mathrm{L-}\left[1^{14} \mathrm{C}\right]$ phenylalanine in diets containing $8 \mathrm{~g} / \mathrm{kg}$ phenylalanine and graded levels of histidine. 'Broken-lines' were fitted by regression analysis; for both the $\mathrm{CO}_{2}$ recovery and for the phenylalaline oxidized the values for dietary histidine levels of $2 \cdot 6-4 \cdot 0 \mathrm{~g} / \mathrm{kg}$ diet were ascribed to the first part of the regression line. Growth rate of the pigs from $3 \mathrm{~d}$ to day of determination (mean with SE): 102 (4) $\mathrm{g} / \mathrm{d}$.

indicating that this was the dietary requirement under the conditions used in the determination.

\section{Influence of dietary histidine level on phenylalanine oxidation}

The adequacy of the dietary histidine level with respect to the catabolism of another essential amino acid, phenylalanine, is shown in Fig. 2. Increasing the histidine level from 2.6 to $4 \mathrm{~g} / \mathrm{kg}$ resulted in a progressive decline in radioactivity recovered in $\mathrm{CO}_{2}$, but further increases up to $6 \mathrm{~g} / \mathrm{kg}$ caused no further reduction in the radioactivity recovered in $\mathrm{CO}_{2}$, suggesting that protein formation was not being limited by the supply of histidine for piglets receiving more than $4 \mathrm{~g}$ histidine $/ \mathrm{kg}$ diet. The specific activity of the liver free phenylalanine varied from 1.2 to $4.8 \times 10^{3}$ disintegrations/min per $\mu \mathrm{mol}$, even though all the dietary treatments provided the same amounts of total phenylalanine and $\left[{ }^{14} \mathrm{C}\right]$ phenylalanine, specific activity of the dietary source of phenylalanine being $15 \times 10^{3}$ disintegrations $/ \mathrm{min}$ per $\mu \mathrm{mol}$. The dilution of exogenous with endogenous phenylalanine was thus between threeand tenfold. The lowest level of dietary histidine resulted in the oxidation of $110 \mu \mathrm{mol}$ phenylalanine $/ \mathrm{kg}$ body-weight per h (Fig. 2), and this was reduced to $24 \mu \mathrm{mol} / \mathrm{kg}$ 


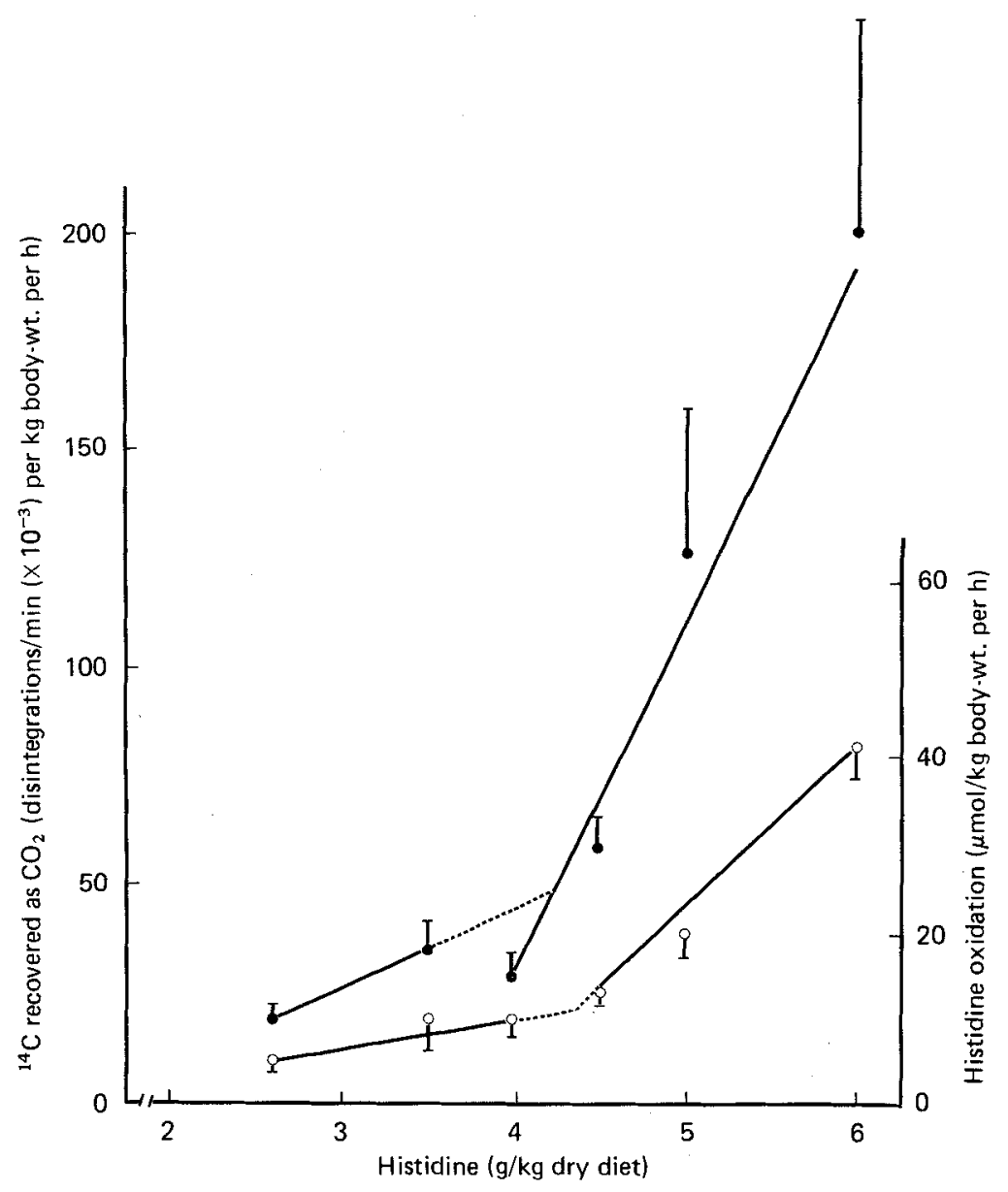

Fig. 3. Influence of dietary histidine level on histidine oxidation. Mean values with their standard errors represented by vertical bars for the radioactivity recovered as carbon dioxide $(-\infty)$ ) and for histidine oxidized $(\mathrm{O}-\mathrm{O})$ in $1 \mathrm{~h}$ by pigs which had received $20 \mu \mathrm{Ci} \mathrm{L}-\left[1-{ }^{14} \mathrm{C}\right]$ histidine in diets containing graded levels of histidine. 'Broken-lines' were fitted by regression analyses; for the $\mathrm{CO}_{2}$ recovery the values for dietary histidine levels of $2 \cdot 6-3 \cdot 5 \mathrm{~g} / \mathrm{kg}$ diet were ascribed to the first part of the regression line, and for the histidine oxidized the values for dietary histidine levels of $2.6-4.0 \mathrm{~g} / \mathrm{kg}$ were ascribed to the first part of the regression line. The change-over points are shown by extrapolation of the lines (-----). Growth rate of the pigs from $3 \mathrm{~d}$ to day of determination (mean with SE): $129(4) \mathrm{g} / \mathrm{d}$.

body-weight per $\mathrm{h}$ by raising the dietary histidine level to $4 \mathrm{~g} / \mathrm{kg}$. This is comparable to the phenylalanine oxidation rate of $15 \mu \mathrm{mol} / \mathrm{kg}$ body-weight per $\mathrm{h}$ observed in the previous experiment with a dietary level of $8 \mathrm{~g}$ phenylalanine $/ \mathrm{kg}$. The greater phenylalanine oxidation rate in the indirect determination of histidine requirement may be related to the lower growth rate of the pigs in the histidine experiment $(102 \mathrm{~g} / \mathrm{d})$ than in the phenylalanine experiment $(155 \mathrm{~g} / \mathrm{d})$. The change-over points for the two portions of the regression lines calculated for the values in Fig. 2 and their 95\% confidence limits were $3.87(3.56-4.19) \mathrm{g}$ histidine $/ \mathrm{kg}$ for the activity recovered as $\mathrm{CO}_{2}$, and $3.77(3.61-3.92) \mathrm{g}$ histidine $/ \mathrm{kg}$ for the oxidation rate of phenylalanine. In this experiment the estimate based on the oxidation of phenylalanine was the more precise. These results show that the histidine requirement was approximately $4 \mathrm{~g} / \mathrm{kg}$ diet. 


\section{Influence of dietary histidine level on histidine oxidation}

Confirmation that $4 \mathrm{~g} / \mathrm{kg}$ was the dietary histidine requirement is provided by the results of the direct determination of histidine requirement shown in Fig. 3, the calculated change-over points and their $95 \%$ confidence limits occurring at dietary histidine levels of $4.26(4.00-4.52)$ and $4.30(3.86-4.75) \mathrm{g} / \mathrm{kg}$ for the lines based on the recovery of radioactivity in $\mathrm{CO}_{2}$ or on the oxidation of histidine respectively. Release of radioactivity in $\mathrm{CO}_{2}$ from $\left[{ }^{14} \mathrm{C}\right]$ histidine was unaffected by dietary histidine levels below $4 \mathrm{~g} / \mathrm{kg}$, but increased in response to higher dietary levels. The specific activity of the liver free histidine ranged between 2.2 and $13.9 \times 10^{3}$ disintegrations $/ \mathrm{min}$ per $\mu \mathrm{mol}$ and was not affected by dietary treatment (Table 3). Comparison of the specific activities for the diet and liver free histidine showed a five- to tenfold dilution of exogenous with endogenous histidine. Less than $10 \mu \mathrm{mol} / \mathrm{kg}$ body-weight per $\mathrm{h}$ histidine were oxidized by the piglets receiving the diets containing less than $4 \mathrm{~g}$ histidine $/ \mathrm{kg}$. This increased to a mean of $41 \mu \mathrm{mol} / \mathrm{kg}$ body-weight per $\mathrm{h}$ for the diet containing $6 \mathrm{~g}$ histidine $/ \mathrm{kg}$.

\section{DISCUSSION}

The possibility of weaning young pigs at or soon after birth either by minimizing the exposure to pathogens (Coalson \& Lecce, 1973) or by providing exogenous immunoglobulin (McCallum et al. 1977) has added some urgency to the definition of nutrient requirements of young pigs. Measurement of amino acid requirements by studying the oxidation of tracer doses of ${ }^{14} \mathrm{C}$-labelled amino acids is potentially useful. However, in a previous report, Chavez \& Bayley (1976) used piglets which were 6-7 weeks of age by the time of the determination. The major objective of the present study was to use younger pigs, but these only exhibit their full growth potential if they receive milk-based diets, and the amino acid levels in such diets are too high to serve as a basis for studying requirements for individual amino acids (Braude et al. 1977).

Dilution of the skim-milk protein with a free amino acid mixture was a compromise between the necessity of having a basal diet deficient in a particular amino acid and the need to study piglets which were growing normally. The growth rates of 155,102 and $129 \mathrm{~g} / \mathrm{d}$ between 3 and $14 \mathrm{~d}$ of age for the piglets in the three experiments receiving diets in which $400 \mathrm{~g} / \mathrm{kg}$ protein was provided as skim milk and the balance as free amino acids are lower than the $208 \mathrm{~g} / \mathrm{d}$ recorded for the piglets on the skim-milk diet in the preliminary study. There are a few reports showing growth curves for piglets in their first 2 weeks of life (for example, Braude, 1972). Coalson \& Lecce (1973) reported gains of $180-250 \mathrm{~g} / \mathrm{d}$ to $14 \mathrm{~d}$ of age for piglets weaned into isolators and fed each hour, but these rapid gains were for piglets receiving milk-based diets. Replacement of the milk by fish products (Newport, 1979) or by plant proteins (Schneider \& Sarett, 1969) resulted in greatly-reduced growth to $14 \mathrm{~d}$ of age.

Feeding the experimental diets with amino acid levels graded from deficient, through sufficient, to excess result in differences in food intake and growth. Several days are required to establish measurable differences, extending the experimental period beyond the first 2 weeks which are of particular interest in the case of the piglet. However, the release of radioactivity from a labelled amino acid in $\mathrm{CO}_{2}$ has been shown to respond to the amino acid levels in the experimental diets within a few hours of their consumption. Thus the short-term observation of the effect of dietary amino acid level on amino acid metabolism obviated the need for a preliminary period during which the piglets received diets with graded levels of the amino acid being studied. Administration of the tracer dose in the diet, and offering the labelled feed in two separate meals before the $\mathrm{CO}_{2}$-collection period, increased the possibilities for uniform mixing of the tracer dose with the amino acids released by digestion of the skim milk with the free amino acids in the diet and with the 
endogenous amino acids. Differences in the flow of milk protein and of the free amino acids from the stomach to the small intestine would be expected, but the uniformity of the specific activity of the liver free phenylalanine over the $3 \mathrm{~h}$ period of the preliminary study suggested that uniform distribution of the labelled phenylalanine was in fact occurring in the liver pool of free amino acids during the $\mathrm{CO}_{2}$-collection period. The large dilution of the dietary phenylalanine and histidine in the liver free amino acid pool may explain why the dietary amino acid concentration had no consistent effect on the specific activities of the liver free phenylalanine or histidine. Kang-Lee \& Harper (1978) found that the specific activity of liver free threonine was not influenced by the dietary threonine levels higher than $1.5 \mathrm{~g} / \mathrm{kg}$.

Analysis of the response of animals to increasing concentration of a nutrient in the diet should be based on an asymptotic curve which approached a maximum (or minimum) as the dietary requirement is reached (Robbins et al. 1979). However, most nutritional experiments which involve discrete increments of dietary nutrient level can be represented by a 'broken-line' model and this allows estimation of the standard error of the estimate of the change-over point between the two parts of the line and hence calculation of the confidence intervals of the requirements indicated by the experimental values. In these three experiments the amino acid requirements were estimated to within $1 \mathrm{~g} / \mathrm{kg}$ diet using radioactivity recovered as $\mathrm{CO}_{2}$ as an index of response. Measurement of the specific activity of the amino acid in the liver free pool improved the precision of the estimation of requirement in two of the three experiments. The similarity between the effect of dietary amino acid level on the recovery of radioactivity in the $\mathrm{CO}_{2}$ and on the calculated amino acid oxidation rate follows from the absence of an effect of dietary amino acid balance on the specific activity of the liver free amino acid. This would allow several observations to be made on the same animal since there is no need to kill the animal at the end of each determination.

Using an indicator amino acid to study the effects of changing the dietary supply of another essential amino acid makes it unnecessary to obtain the carboxyl-labelled L-isomers of all the essential amino acids, many of which are not commercially available. The initial report of the use of amino acid oxidation as a means of establishing dietary requirements (Brookes et al. 1972) included a study of the influence of dietary lysine level on the oxidation of $\left[{ }^{14} \mathrm{C}\right]$ methyl methionine and showed that methionine oxidation was unaffected by the level of lysine. The metabolism of phenylalanine is simpler than that of methionine which does more than contribute methionine residues for protein synthesis. This may account for the suitability of phenylalanine, which was chosen as an indicator amino acid for the present study because it was the lowest-priced $\left[{ }^{14} \mathrm{C}\right]$ carboxyl-labelled essential amino acid which is degraded in the liver. This technique could be applied to the definition of the requirements for other essential amino acids and may be appropriate for making rapid measurements of the effects of any of the factors which influence protein accretion and hence growth. With the elimination of the need to measure the specific activity of the liver free phenylalanine, a sequence of determinations on the same animal are possible, allowing the effects of genetic and environmental modifications to be studied.

The limited scope for manipulation of the diet of the young pig without impairing health or productivity have virtually precluded growth experimentation to define the nutrient requirements of the piglet during the first 3 weeks of its life. The (US) National Research Council (1979) contains a detailed listing of the requirements for each essential amino acid for piglets of $1-5 \mathrm{~kg}$ body-weight but cautions that the diet must contain a 'substantial' level of milk products. Examination of the tabulated amino acid requirements for 1-5 and 5-10 kg piglets shows that those for the smaller piglets have been derived from the larger ones by multiplication with the appropriate factor which reflects the higher recommended level of protein for the smaller pigs: 270 rather than $200 \mathrm{~g} / \mathrm{kg}$.

Both the indirect and direct measurements of histidine requirements showed that the 
piglets responded by increasing the conservation of amino acids to increases in the level of dietary histidine to $4 \mathrm{~g} / \mathrm{kg}$. This is almost one-third higher than the recommendation of $3 \cdot 1 \mathrm{~g} / \mathrm{kg}$ ((US) National Research Council, 1979) and indicates that young piglets need a greater proportion of histidine in their diets than older piglets on which the current recommendations are, in effect, based. Histidine is required for the synthesis of carnosine, and Atkinson (1977) showed that the concentration of carnosine in the muscle increases tenfold during the first $21 \mathrm{~d}$ of the piglet's life. This higher value for the young piglet compared to that of older pigs suggests the importance of applying an amino acid oxidation technique to studying the metabolic response of piglets to other essential amino acids. More precise definition of the dietary requirements for these nutrients may allow alternate dietary formulations which would reduce the dependency of the young piglets on milk products as the main source of dietary protein.

This work was supported by the National Research Council of Canada, Agriculture Canada and the Ontario Ministry of Agriculture and Food. The authors are grateful for the skilled assistance of Keith D'Eall and Margaret Quinton.

\section{REFERENCES}

Adams, R. F. (1974). Journal of Chromatography 95, 189-212.

Atkinson, J. L. (1977). Substrate utilization and fasting metabolism during postnatal development of the pig. PhD Thesis, University of Guelph.

Braude, R. (1972). Second World Congress of Animal Feeding, Madrid, pp. 641-656.

Braude, R., Keal, H. D., \& Newport, M. J. (1977). British Journal of Nutrition 37, 187-194.

Brookes, I. M., Owens, F. N. \& Garrigus, U. S. (1972). Journal of Nutrition 102, 27-35.

Chavez, E. R. \& Bayley, H. S. (1976). British Journal of Nutrition 36, 369-380.

Coalson, J. A. \& Lecce, J. G. (1973). Journal of Animal Science 36, 1114-1121.

Draper, N. R. \& Smith, H. (1981). Applied Regression Analysis, 2nd ed. New York: John Wiley.

Elwyn, D. H. (1970). In Mammalian Protein Metabolism, vol. 4, p. 523 [H. N. Munro, editor]. New York: Academic Press.

Fricke, U. (1975). Analytical Biochemistry 63, 555-558.

Kang-Lee, Y. A. \& Harper, A. E. (1977). Journal of Nutrition 107, 1427-1443.

Kang-Lee, Y. A. \& Harper, A. E. (1978). Journal of Nutrition 108, 163-175.

McCallum, I. M., Elliot, J. I., \& Owen, B. D. (1977). Canadian Journal of Animal Science 57, $151-158$.

National Research Council (1979). Nutrient Requirements of Domestic Animals, no. 2, Nutrient Requirements of Swine, 8th ed. Washington, DC: National Academy of Science.

Newport, M. J. (1979). British Journal of Nutrition 41, 103-110.

Robbins, K. R. \& Baker, D. H. (1978). Candian Journal of Animal Science 58, 533-535.

Robbins, K. R., Norton, H. W. \& Baker, D. H. (1979). Journal of Nutrition 109, 1710-1714.

Rogers, Q. R. \& Harper, A. E. (1965). Journal of Nutrition 87, 267-273.

Schneider, D. L. \& Sarett, H. P. (1969). Journal of Nutrition 98, 279-287.

Seber, G. A. F. (1977). Linear Regression Analysis. New York: John Wiley. 